scarcely been introduced into English asylums Not only will they be doing a patriotic duty by introducing these female nurses to enable more of their male attendants to enlist, but they can be assured that they will at the same time be adding to the comfort and well-being of the sick and infirm male patients under their charge.

I am, Sir, yours faithfully,

GEORGE M. RoBERTSON, M.D., Phssician-Superintendent.

The Royal Asylum, Morningside, Edinburgh, July 2lst, 1915.

\section{THE TREATMENT OF INJURY OF THE} MEMBRANA TYMPANI DUE TO BURSTING SHELLS.

\section{To the Editor of THE LANOET.}

SIR,-One of the lesser features of the war is the large number of cases of injury to the membrana tympani due to the bursting of high-explosive shells. A mere slit or hole may be produced, but in many cases there is absolute destruction of a large part or whole of the membrana tensa. The treatment of these cases is very simple. The deep meatus and membrane should be left absolutely alone, no drops or syringing being used. The cartilaginous meatus should be painted with iodine, care being taken that none reaches the deep meatus, and then carefully and lightly plugged with sterile gauze or wool, which can be changed as often as is necessary. As a rule, healing will take place in about two months' time without pain or purulent discharge, and with nearly perfect hearing if the labyrinth has not also been injured. If infection does take place and a purulent discharge result, the ear should be gently syringed with warm sterile boric lotion or normal saline solution two or three times a day, wool being worn in the intervals. These cases strongly resent the application of peroxide of hydrogen or any strong antiseptic solution.

I am, Sir, yours faithfully,

Savile-row, W., July 26th, 1915.

Arthur H. Cheatre.

\section{THE NOTIFICATION OF BIRTHS EXTEN- SION BILL.}

To the Editor of THE LANCET.

SIR,-One point in Dr. R. R. Rentoul's letter on the above Bill in THE LANCET of July 24th should, I think, be strenuously urged upon the legislature by the profession-viz., the gross unfairness of compelling a medical man without fee to notify within 48 hours each birth at which he attends. I have repeatedly felt the injustice of this compulsion. As yet I have failed to find any other part of the community required to give information sufficiently important to need a compulsory Act without any fee or payment attaching.

I am, Sir, yours faithfully,

Dalston, July 26th, 1915. F. E. COCKELL.

\section{EVOLUTIONARY ETIOLOGICAL FACTORS IN DISEASE.}

To the Editor of THE LANCET.

SIR,-The contribution by Dr. R. Donaldson in The LANCET of June 26th on the Etiological Factor in So-called Cerebro-spinal Fever is of particular interest, perhaps more especially to those who for years past have attacked the doctrine of absolute specificity in the matter of infectious diseases. That specificity is merely relative, not absolute, is a thesis which has been strongly supported by many authorities and which I have tried to elaborate elsewhere. ${ }^{1}$ Some diseases, such as variola and morbilli, are more definitely specific than others; yet in my little book arguments are adduced that these two diseases may be more closely related than is generally imagined, possibly evolving from a common ancestral organism. Dr. Donaldson's bacteriological observations support an idea which I have entertained for some months on clinical and epidemiological grounds that so.called cerebro-spinal fever is more or less related to diphtheritic and scarlatinal infection, evolving by way of some anomalous form of sore-throat.

Last autumn and winter there was widely prevalent in Norfolk (and probably in other counties) a peculiar form of infectious disease characterised generally by a moderate sore-throat, and occasionally by a slight and evanescent rash (said to be scarlatiniform in character); in a few cases the tongue was beefy or showed enlarged fungiform papillæ. Fever was moderate, rarely exceeding $101^{\circ} \mathrm{F}$.; pulse rarely over 110 , even in children; the body was not hot to the touch. Vomiting was rare, as also was any sign of desqua. mation. Swabbings of throats gave variable results, the most frequent organism present being a nonGram-staining diplococcus, which Professor R. T. Hewlett reported might be Micrococcus catarrhalis. Hofmann's bacillus was also frequently noted. Later, when cases of so-called cerebro-spinal fever began to crop up, I could not help associating its appearance in my mind with the widely spread epidemic of sore-throats which preceded it, particularly when it became clear by extensive bacteriological examination of swabbings from contacts of cerebro-spinal ferer cases that for every clinical case of so-called cerebro-spinal fever there were several carriers of the so-called "meningococcus," who appeared to be quite well or merely to have a little catarrh.

I have elsewhere recorded the opinion that on clinical, epidemiological, and bacteriological grounds there is a subtle relationship between scarlet fever and diphtheria, and Hofmann and other anomalous forms of sore-throat. Hort and others have questioned the specificity of the meningococcus, and now Dr. Donaldson suggests that the causal organism of the epidemic of cerebrospinal fever recently noted in Reading is a diphtheroid rod closely related to Klebs-Löffler's bacillus; this diphtheroid rod (like the diphtheria bacillus) being extremely pleomorphous, giving rise to Hofmann-like forms, to what appear to be meningococci, \&c. Some years ago I contributed a note (THE LANCET, Sept. 21st, 1907) on a case of malignant endocarditis of diphtheritic origin, in which the terminal symptoms suggested the possi. bility of cerebro-spinal fever. A post-mortem examination (which included the removal of cerebrospinal fluid by a lumbar puncture) revealed on further bacteriological investigation that both the cerebro-spinal fluid and the cardiac valvular vegetations contained Klebs-Löffler bacilli in pure culture. In view of Dr. Donaldson's researches, it may be not only interesting but useful to recall this almost unique record of a case of diphtheritic septicæmia to mind. The earlier symptoms of sore-throat had been very mild, and it was only by a close cross. examination of the parents after diphtheria bacilli were found post mortem that a history was obtained

1 Evolution and Disegase. Bristol: John Wright and Sr.z.8, Limited. 